\title{
METHANE POTENTIAL FROM HOUSEHOLD GARDEN LEAVES
}

\author{
Vilis Dubrovskis, Imants Plume \\ Latvia University of Life Sciences and Technologies, Latvia \\ vilisd@inbox.lv, imants.plume@1lu.lv
}

\begin{abstract}
Every year a huge amount of different tree leaves is collected in Latvian household gardens. They are taken away to landfills or stored in large piles, most often in municipal areas, as transportation to sparse landfills has now become expensive. Large piles are called compost piles, but in fact the composting process in them is weak because there is no good oxygen supply. Anaerobic processes begin in the lower layers of the heap and, in fact, there is more pollution than if the leaves were left under the trees and decomposed by aerobic bacteria. The problem could be solved if these leaves were recycled in biogas plants. What is the potential of some leaves for methane extraction was clarified in this study. Maple, grape, apple, cherry and pear leaves were anaerobically processed in 16 laboratory bioreactors at $38^{\circ} \mathrm{C}$. After 32 days of processing, $0.526 \mathrm{~L} \cdot \mathrm{g}^{-1} \mathrm{DOM}$ biogas was obtained from maple leaves $\left(0.28 \mathrm{~L} \cdot \mathrm{g}^{-1}\right.$ DOM methane), $0.471 \mathrm{~L} \cdot \mathrm{g}^{-1}$ DOM biogas from grape leaves $\left(0.214 \mathrm{~L} \cdot \mathrm{g}^{-1}\right.$ DOM methane), $0.723 \mathrm{~L} \cdot \mathrm{g}^{-1}$ DOM biogas was obtained from apple leaves $\left(0.262 \mathrm{~L} \cdot \mathrm{g}^{-1}\right.$ DOM methane) and from a mixture of cherry and pear leaves $0.769 \mathrm{~L} \cdot \mathrm{g}^{-1}$ DOM biogas $\left(0.338 \mathrm{~L} \cdot \mathrm{g}^{-1}\right.$ DOM methane). It has been concluded that chopped garden leaves are a good raw material for methane production.
\end{abstract}

Keywords: anaerobic digestion, methane, maple, grape, apple, cherry and pear leaves.

\section{Introduction}

Every year a huge amount of different tree leaves is collected in Latvian household gardens. They are taken away to landfills or stored in large piles, most often in municipal areas, as transportation to sparse landfills has now become expensive. Large piles are called compost piles, but in fact the composting process in them is weak because there is no good oxygen supply. Anaerobic processes begin in the lower layers of the heap and, in fact, there is more pollution than if the leaves were left under the trees and decomposed by aerobic bacteria.

During the growth process, leaves accumulate a large number of toxic substances that enter the air with exhaust gases. When foliage is burned, carbon monoxide and carbon dioxide, benzapyrene with carcinogenic properties, and dioxins are released. From one ton of burnt leaves up to $30 \mathrm{~kg}$ of toxic compounds enter the air. The problem could be solved, if these leaves were recycled in biogas plants. Fallen leaves can bring considerable benefits and save money on gasoline, natural gas and other energy resources. But most importantly, leaf recycling using anaerobic fermentation technology can improve the ecological situation in the city. Other researchers write about the usefulness of tree leaves for energy production. "Using urban fallen leaves as potential resource of energy could not only benefit in environmental and economical aspects, but also improve the efficiency of urban energy systems, introducing using of new renewables and encouraging utilizing other urban green waste in biomass-forenergy consumption" [1;2].

Biogas yields from leaves depends on many parameters: composition of the substrate; type of technology and equipment used; compliance with technological conditions (heating, etc.).

According to reports, the biogas yield from 1 ton of leaves is 2.85-3 cubic meters. Consequently, from 120 thousand tons (we take the data for Kiev), you can get 342 thousand cubic meters of gas. It is a gas mixture with a methane content of up to $60 \%$. In terms of natural gas, this is about $210000 \mathrm{~m}^{3}$ [3].

In our 2012 study with mixed city park tree leaves, we obtained the following results. The average specific biogas production yield $377 \pm 22 \mathrm{~L} \cdot \mathrm{kgVSA}^{-1}$ with the average methane content $50.2 \%$ was obtained from fallen leaves [1]. Further improvement of biogas output from fallen leaves can be achieved through different pre-treatment techniques, e.g., fine shredding, steam heating and/or chemical treatment, improving lignin biodegradability.

Another study showed that the biogas yield reached $321 \mathrm{~mL} \cdot \mathrm{g}^{-1} \mathrm{VS}$ for poplar leaf co-digestion with swine manure [4]. However, few studies have investigated the anaerobic digestion characteristics of poplar leaf as the sole feedstock. ,In this study, the effect of combined pretreatment on the anaerobic digestion of poplar leaves as the sole substrate is conducted. The objective of the study is to: (1) test the anaerobic digestion performance when poplar leaves are used as the sole substrate after combined 
pretreatment and (2) determine the best combination of pretreatment condition parameters and the optimal condition for anaerobic digestion', [4].

What is the methane potential of maple leaves, grape leaves, apple leaves and cherry leaves mixed with pear leaves for methane extraction was clarified in this study. Data on the biogas yield from such leaves could not be found in literature. Therefore, the yield of biogas from poplar leaves is shown.

\section{Materials and methods}

The study used methodologies similar to those in Germany and Denmark [5-7]. Fallen leaves were collected in the garden of one household. Grape leaves were collected in a greenhouse. All leaves were determined for total dry matter and dry organic matter content.

Dry organic matter (DOM) content was determined by weighting of the initial biomass samples, drying in dry matter weights Shimazu at $105^{\circ} \mathrm{C}$ and then placed for ashing in the oven ("Nabertherm" type) at $550^{\circ} \mathrm{C}$. Gas volumes were measured using a water batch. The composition of gases, including oxygen, carbon dioxide, methane, and hydrogen sulphide was measured by help of a gas analyser (model GA2000). The substrate $\mathrm{pH}$ value was measured before and after finishing off the AD process, using a pH meter (model PP-50) with accessories. Scales (Kern, model KFB 16KO2) was used for weighting of the total weight of substrates before and after the AD process [6; 7]. Sixteen 0.75 liter bioreactors were used for the study. Bioreactors R2-R4 were filled in with inoculum $500 \mathrm{~g}$ and $20 \mathrm{~g}$ chopped maple leaves, bioreactors R5-R7 were filled in with 500g inoculum and $20 \mathrm{~g}$ chopped grape leaves. Bioreactors R8-R11 were filled in with $500 \mathrm{~g}$ inoculum and $20 \mathrm{~g}$ chopped apple leaves, bioreactors R12-R15 were filled in with $500 \mathrm{~g}$ inoculum and $20 \mathrm{~g}$ chopped mixed cherry with pear leaves (proportions 1:1). Bioreactors R1 and R16 were filled in with $500 \mathrm{~g}$ inoculum only.

Fermented cattle manure (from $110 \mathrm{~L}$ bioreactor working in continuous mode) was used as the inoculum. Batch mode $\mathrm{AD}$ process was ongoing at temperature $38 \pm 0.5^{\circ} \mathrm{C}$. Biogas released was collected in gas bags for further measurements of the gas volume and elemental composition. Biogas and methane volumes and gas composition were measured during the $\mathrm{AD}$ process at regular time intervals. The AD process was provided until biogas emission ceases (32 days). The obtained experimental data were processed using appropriate statistical methods [6;7].

\section{Results and discussion}

The results of investigation of sample substrates, including inoculums, maple leaves, grape leaves, apple leaves and cherry and pear leaves mixture, before starting of the AD process are shown in Table 1.

Analyses of raw material samples before anaerobic digestion

Table 1

\begin{tabular}{|c|c|c|c|c|c|c|c|c|}
\hline $\begin{array}{c}\text { Bio- } \\
\text { reactors }\end{array}$ & Raw material & $\mathbf{p H}$ & $\begin{array}{c}\text { TS, } \\
\mathbf{\%}\end{array}$ & $\begin{array}{c}\text { TS, } \\
\mathbf{g}\end{array}$ & $\begin{array}{c}\text { ASH, } \\
\mathbf{\%}\end{array}$ & $\begin{array}{c}\text { DOM, } \\
\mathbf{\%}\end{array}$ & $\begin{array}{c}\text { DOM, } \\
\mathbf{g}\end{array}$ & $\begin{array}{c}\text { Weight, } \\
\mathbf{g}\end{array}$ \\
\hline R1; R16 & IN & 7.68 & 3.8 & 19.0 & 26.48 & 73.52 & 13.969 & 500 \\
\hline R2-R4 & ML & - & 77.49 & 15.498 & 21.08 & 78.92 & 12.231 & 20 \\
\hline R2-R4 & 20 ML + 500IN & 7.67 & 6.63 & 34.498 & 24.05 & 75.95 & 26.20 & 520 \\
\hline R5- R7 & 20 GL & - & 61.0 & 12.2 & 14.67 & 85.33 & 10.41 & 20 \\
\hline R5-R7 & 20 GL + 500IN & 7.65 & 6.0 & 31.2 & 21.86 & 78.14 & 24.375 & 520 \\
\hline R8-R11 & 20 AL & - & 31.79 & 6.358 & 30.94 & 69.06 & 4.39 & 20 \\
\hline R8- R11 & 20 AL + 500IN & 7.67 & 4.88 & 25.358 & 27.60 & 72.40 & 18.359 & 520 \\
\hline R12-R15 & CHPL 20 & - & 39.44 & 7.888 & 11.39 & 88.61 & 6.99 & 20 \\
\hline R12-R15 & CHPL 20 + 500 IN & 7.67 & 5.17 & 26.888 & 22.05 & 77.95 & 20.959 & 520 \\
\hline
\end{tabular}

Note: IN - inoculum; ML - maple leaves; GL - grape leaves; AL - apple leaves; CHPL -cherry and pear leaves; TS - total solids; DOM - dry organic matter (on raw substrate basis);

$\mathrm{R} 1$ - R16 - bioreactors.

As it can be seen from Table 1, the maple and grape leaves have a high dry matter content. This is due to the fact that these leaves were collected and stored for a long time in the greenhouse. The remaining garden leaves were collected in the morning of the study start day and were therefore less dry. The content of cherry and pear leaves in the sample is similar. 
Biogas and methane yields

Table 2

\begin{tabular}{|c|c|c|c|c|c|}
\hline Bioreactor/Raw material & $\begin{array}{c}\text { Biogas, } \\
\text { L }\end{array}$ & $\begin{array}{c}\text { Biogas, } \\
\text { L. } \mathbf{g}^{-1} \text { DOM }\end{array}$ & $\begin{array}{c}\text { Methane, } \\
\text { aver. } \%\end{array}$ & $\begin{array}{c}\text { Methane, } \\
\text { L }\end{array}$ & $\begin{array}{c}\text { Methane, } \\
\text { L.g }{ }^{-1} \text { DOM }\end{array}$ \\
\hline R1 500 IN & 0.4 & 0.029 & 6.75 & 0.027 & 0.002 \\
\hline R16 500 IN & 0.4 & 0.029 & 8.50 & 0.034 & 0.002 \\
\hline Average R1, R16 & 0.4 & 0.029 & $\mathbf{7 . 6 3}$ & $\mathbf{0 . 0 3 1}$ & 0.002 \\
\hline R2 500 g IN + 20 g ML & 7.0 & 0.572 & 54.0 & 3.78 & 0.309 \\
\hline R3 500 g IN + 20 g ML & 7.0 & 0.572 & 55.01 & 3.851 & 0.315 \\
\hline $\mathrm{R} 4500 \mathrm{~g} \mathrm{IN}+20 \mathrm{~g} \mathrm{ML}$ & 5.3 & 0.433 & 49.85 & 2.642 & 0.216 \\
\hline Average R2- R4 ML & 6.433 & 0.526 & 52.95 & 3.424 & 0.280 \\
\hline \pm st.dev. & 0.981 & 0.08 & 2.375 & 0.678 & 0.056 \\
\hline R5 500 g IN + 20 g GL & 6.0 & 0.576 & 45.9 & 2.754 & 0.264 \\
\hline R6 500 g IN + 20 g GL & 2.9 & 0.279 & 45.09 & 1.307 & 0.126 \\
\hline R7 500 g IN + 20 g GL & 5.8 & 0.557 & 45.21 & 2.622 & 0.252 \\
\hline Average R5-R7 GL & 4.4 & 0.471 & 45.4 & 2.228 & 0.214 \\
\hline \pm st.dev. & 1.735 & 0.166 & 0.437 & 0.8 & 0.076 \\
\hline R8 500 g IN + 20 g AL & 3.2 & 0.729 & 53.94 & 1.086 & 0.247 \\
\hline R9 $500 \mathrm{~g} \mathrm{IN}+20 \mathrm{~g} \mathrm{AL}$ & 3.1 & 0.706 & 37.65 & 1.167 & 0.266 \\
\hline R10 500 g IN + 20 g AL & 3.1 & 0.706 & 36.61 & 1.135 & 0.259 \\
\hline R11 $500 \mathrm{~g}$ IN + $20 \mathrm{~g} \mathrm{AL}$ & 3.3 & 0.751 & 36.45 & 1.203 & 0.274 \\
\hline Average R8-R11 AL & 3.175 & 0.723 & 41.16 & 1.148 & 0.262 \\
\hline \pm st.dev. & 0.096 & $\mathbf{0 . 0 2 2}$ & 8.535 & 0.05 & 0.011 \\
\hline R12 500 g IN + 20 g CHPL & 5.4 & 0.773 & 42.22 & 2.28 & 0.326 \\
\hline R13 $500 \mathrm{~g}$ IN + $20 \mathrm{~g}$ CHPL & 5.6 & 0.801 & 46.13 & 2.583 & 0.370 \\
\hline R14 500 g IN + 20 g CHPL & 5.0 & 0.715 & 41.72 & 2.086 & 0.298 \\
\hline R15 500 g IN + 20 g CHPL & 5.5 & 0.787 & 45.69 & 2.513 & 0.360 \\
\hline AverageR12-R15 CHPL & 5.375 & 0.769 & 43.94 & 2.366 & $\mathbf{0 . 3 3 8}$ \\
\hline \pm st.dev. & 0.263 & 0.038 & 2.291 & 0.227 & 0.035 \\
\hline
\end{tabular}

Note: $\mathrm{L} \cdot \mathrm{g}^{-1}$ DOM - litres per $1 \mathrm{~g}$ dry organic matter added (added fresh biomass into inoculums).

Most of the methane from dry organic matter came from a mixture of cherry and pear leaves. This could be explained by the fact that the mixture also had recently fallen leaves that contained more juice. Specific average biogas and methane yields from maple leaves, grape leaves, apple leaves and mixed cherry with pear leaves are shown in Fig. 1 and the average methane content in Fig. 2.

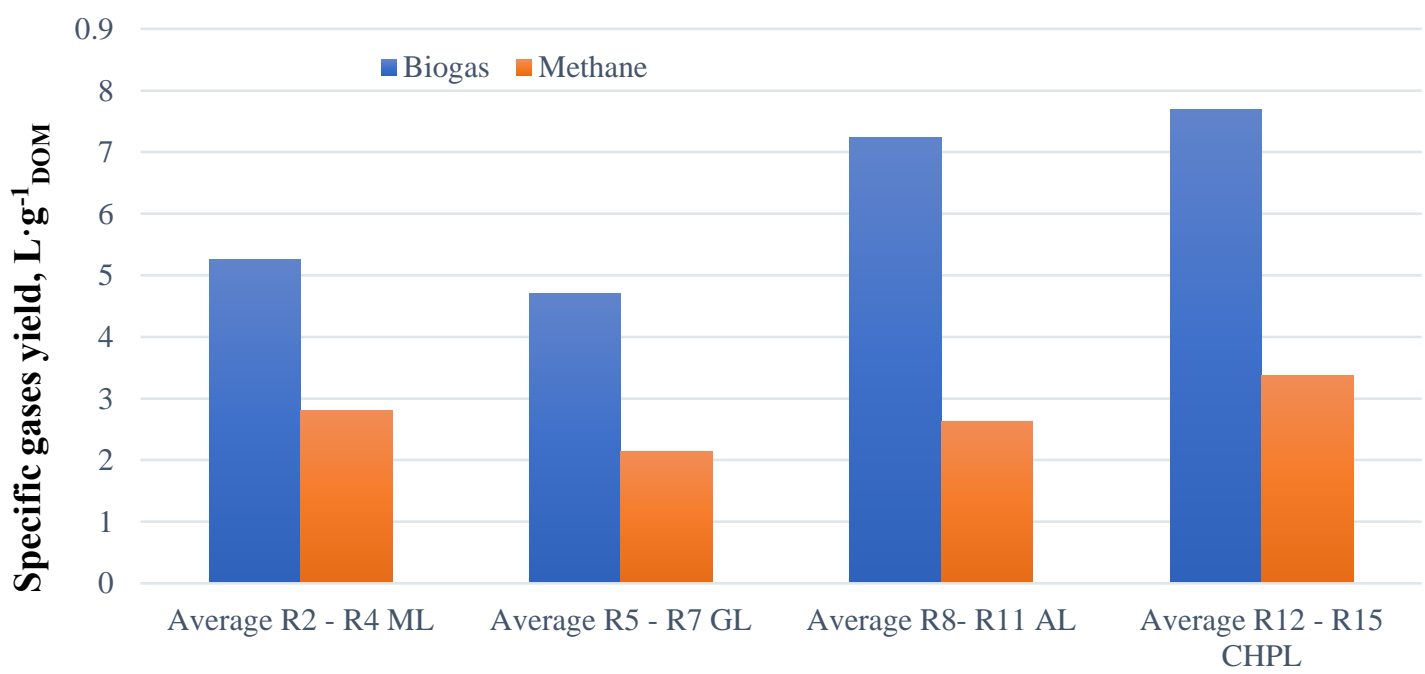

Fig. 1. Specific average biogas and methane yields from maple leaves, grape leaves, apple leaves and mixed cherry with pear leaves 


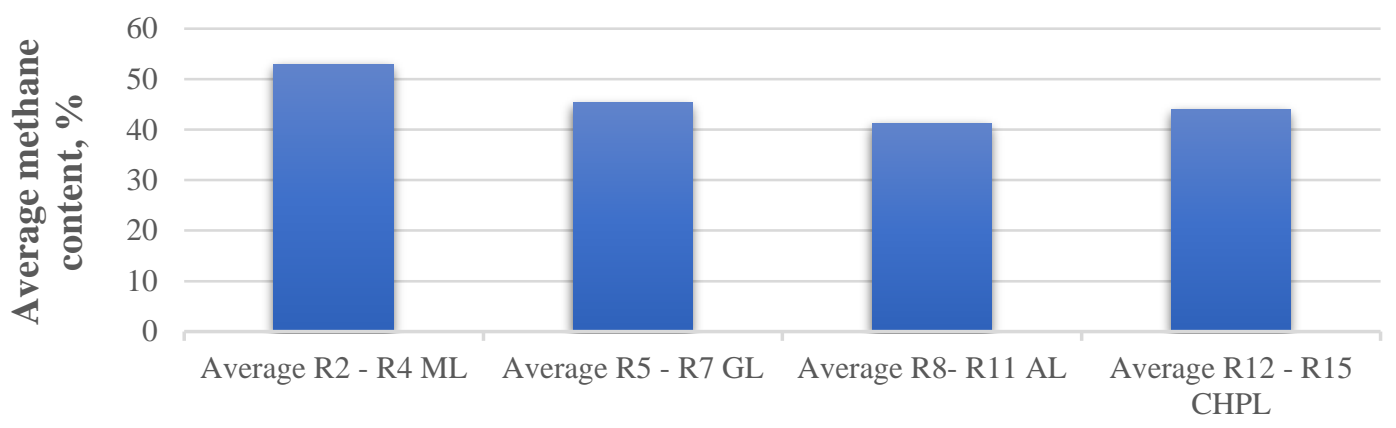

Bioreactors

Fig. 2. Average methane content

It was not possible to compare our results with the data of other researchers, because we did not find studies on the potential of methane from such leaves in the literature.

Compared to other feedstocks used in biogas plants, the lower methane content could be explained by the fact that the leaves were already dry and contained a lot of cellulose, hemicellulose, as well as lignin. The leaves have a high carbon content, so it is desirable to use them in co-fermentation with raw materials with a higher nitrogen content in order to have a better $\mathrm{C} / \mathrm{N}$ ratio.

\section{Conclusions}

1. The average yield of biogas (methane) from the bioreactors with added maple leaves was $0.526 \mathrm{~L} \cdot \mathrm{g}^{-1}$ DOM $\left(0.280 \mathrm{~L} \cdot \mathrm{g}^{-1}\right.$ DOM $)$.

2. The average yield of biogas (methane) from the bioreactors with added grape leaves was $0.471 \mathrm{~L} \cdot \mathrm{g}^{-1}$ DOM $\left(0.214 \mathrm{~L} \cdot \mathrm{g}^{-1}\right.$ DOM $)$.

3. The average yield of biogas from the bioreactors with added apple leaves was $0.723 \mathrm{~L}^{-\mathrm{g}^{-1}} \mathrm{DOM}$ $\left(0.262 \mathrm{~L} \cdot \mathrm{g}^{-1}\right.$ DOM $)$.

4. The average yield of biogas from the bioreactors with added apple leaves was $0.769 \mathrm{~L} \cdot \mathrm{g}^{-1} \mathrm{Dom}$ $\left(0.338 \mathrm{~L} \cdot \mathrm{g}^{-1} \mathrm{DOM}\right)$.

5. Household garden leaves can be a good raw material for biogas production.

\section{Acknowledgements}

This work has been supported by the project G4 "Feasibility Study of Biomass Anaerobic Fermentation Process Efficiency".

\section{References}

[1] Dubrovskis V., Plume I., Kazulis V., Celms A., Kotelenecs V., Zabarovskis E. Biogas production potential from agricultural biomass and organic residues in Latvia. Proceedings of Engineering for Rural Development. 2012, pp. 566-571.

[2] Nikitina M. Urban fallen leaves biomass-new Biofuel? Econoving Bulletin of Science \& Sustainability - EBSS 2013, vol. 2 pp. 18-23.

[3] Ecodevelop: biogas stations. [online][21.03.2021] Available at: https://ecodevelop.ua/en/

[4] Li W., Zhang L., Xu G. Enhancement of biogas yield of poplar leaf by high-solid codigestion with swine manure. Appl. Biochem. Biotechnol. 2016, 179 (2): pp. 270-282.

[5] Angelidaki I., Alves M., Bolzonella D., Borzacconi L., Campos J., Guwy A., Kalyuzhnyi S., Jenicek P., Van Lier J. Defining the biomethane potential (BMP) of solid organic wastes and energy crops: a proposed protocol for batch assays. Water Sci.Technol. 2009, 59(5): pp. 927-934.

[6] Thran D. Methodenhandbuch Energetische Biomassenutzung, (Methods Manual Energetic use of biomass), 2010, Leipzig, 161 p. (In German).

[7] VDI 4630. Vergärung organischer Stoffe Substrat charakterisierung, Probenahme, Stoffdatenerhebung, Gärversuche. Vereindeutscher Ingenieure (Fermentation of organic substances Substrate characterization, sampling, substance data collection, fermentation tests. German engineers), Düsseldorf, 2006, 48 p. (In German). 